\title{
THE PROBLEM OF FORMATION MANAGEMENT COMPETENCE FUTURE SPECIALISTS \\ OF THE SOCIAL SPHERE
}

\section{ПРОБЛЕМА ФОРМУВАННЯ УПРАВЛІНСЬКОЇ КОМПЕТЕНТНОСТІ У МАЙБУТНІХ ФАХІВЦІВ СОЦІАЛЬНОЇ СФЕРИ}

\section{Tetyana Holubenko ${ }^{1}$ \\ Iryna Polishchuk ${ }^{2}$}

DOI: https://doi.org/10.30525/978-9934-26-077-3-11

Abstract. The article substantiates the purpose, stages, content, algorithm and methods of implementation. The entry of Ukrainian higher education into the European space determines the need for specialists with integrated specialties. The purpose of the article is to investigate the purposefulness of the formation of managerial competence in future professionals in the social sphere to ensure the educational and methodological process in higher education institutions. Methodology - general industry, research, information, diagnostic, subject methodical. Thus, there is a need to modernize professional and human resources. Therefore, the issue of scientific understanding of quality training of social workers in management, i.e., leadership of small and large groups of people, their ability to be highly qualified professionals with established managerial competence. Modern approaches to understanding the process of formation of managerial competence in future professionals in the social sphere, which is determined by the focus on the object of management, taking into account its specifics and the nature of development in the socio-educational environment. Based on the analysis of scientific sources, the essence and content of the concept of «managerial competence» are revealed. The understanding of professional training as an important component of

\footnotetext{
${ }^{1}$ Candidate of Pedagogical Sciences, Ph.D,

Associate Professor at the Department of Theory and Technology of Social Work, National Pedagogical Dragomanov University, Ukraine

${ }^{2}$ Senior Lecturer at the Department of Theory and Technology of Social Work, National Pedagogical Dragomanov University, Ukraine
} 
managerial competence of future specialists in the field of management is highlighted, in particular, that professional training is a set of knowledge, skills and abilities, mastery of which allows a person to work as a specialist or a skilled worker qualifications. The main purpose of the formation of managerial competence in future professionals in the social sphere is to achieve a high level of its main components and ensure the manageability of the educational and methodological process. Based on the analysis of pedagogical, methodological, philosophical research of the essence, content and structure of managerial competence in social specialists, the founders revealed as a component of professional competence of a social specialist, a dynamic integrated systemic education, which is manifested in management. In turn, management activity is the result of managerial training of a social worker to evaluate his or her professional activity. Professional training of future social professionals for management is a necessary component that requires clarification of the concept of «professional training of social professionals» in order to form managerial competence for effective performance of professional duties and opportunities for successful work in the chosen profession.

\section{1. Вступ}

На сучасному етапі трансформація соціально-економічних процесів в Україні зумовили необхідність модернізації управління соціальною сферою, вдосконалення управлінського механізму на принципах демократії та гуманізації, цінності людських ресурсів, конкурентоспроможності, відкритості, компетентності і плановості.

Соціально-економічні зміни потребують сучасної високотехнологічної, соціально-ефективної освітньої системи, яка здатна забезпечити виконання іiї головної функції - підготовку фахівців соціальної сфери, соціально адаптованих, здатних задовольнити вимоги соціальних структур, а також упродовж всього життя самостійно здобувати й оновлювати знання та вміння, які необхідні для продуктивної професійної діяльності.

Відповідно на ці вимоги є переорієнтація професійної підготовки у закладах вищої освіти на компетентнісний підхід, що визначено у Національній стратегії розвитку освіти на 2012-2021 pp. На сьогодні виникла ситуація, коли країна має велику кількість фахівців з вищою 
освітою, а реально соціальним установам бракує компетентних, практико-орієнтованих управлінських кадрів.

Професійна підготовка фахівців соціальної сфери, яка базується тільки на традиційній концепції навчання, не може забезпечити в повній мірі якісну підготовку майбутніх фахівців соціальної сфери, які здатні розв'язувати складні проблеми соціального розвитку країни. Як проказує практичний досвід, що завжди в рамках такої парадигми актуальною $€$ проблема наявності знань і умінь їх реалізувати на практиці.

В Україні накопичено позитивний досвід професійної підготовки фахівців соціальної сфери у системі вищої освіти. Соціально-економічні процеси зумовлюють необхідність постійного внесення коректив у зміст їх підготовки в теоретичну та практичну складові.

Входження української вищої освіти в європейський простір зумовлює потребу у фахівцях 3 інтегрованими спеціальностями. Таким чином виникає необхідність у модернізації професійно-людських pecyрсах. Тому дуже актуальним постає питання у науковому осмисленні якісної підготовки фахівців соціальної сфери до менеджменту, тобто керівництва малими та великими групами людей, їх здатності бути висококваліфікованими фахівцями із сформованою управлінською компетентністю.

Українська і зарубіжна педагогіка накопичила позитивний досвід професійної підготовки фахівців у системі вищої освіти. Її важливі аспекти висвітлені в наукових працях таких фундаторів, як Г. Алтухової, Ю. Арутюнова, С. Батишева, І. Беха, М. Вандер Венде, Л. Володарської-Золи, Т. Горячевої, В. Гриненка, С. Зигмантович, Н. Ничкало, А. Почтовюк, В. Семиченко, О. Соколова, Ю. Фокіна та ін. Проблеми професійної підготовки фахівців у галузі управління визначено у працях філософів (Т. Бірюкова, Н. Лукашевич, І. Ходикіна), фундаторів психології (О. Гринчук, С. Дубов, І. Слісеєва, Б. Жиганов), фундаторів педагогіки (О. Карпенко, Н. Романова, О. Романовський, В. Топоровський). Питання підготовки менеджерів у закладах вищої освіти висвітлена у працях вітчизняних і зарубіжних учених О. Аксьонової, Н. Давиденко, О. Кузнєцової, В. Локшина, Л. Паращенко, які вивчали проблеми формування управлінського мислення студентів. Формування управлінської компетентності як предмет дослідження висвітлено у працях В. Бондаря, І. Васюкова, Р. Вдовиченко, Г. Сльникової та ін. 
Результати аналізу, здійснених за останнє десятиліття досліджень проблеми формування управлінської компетентності у майбутніх фахівців соціальної роботи свідчать про те, що зацікавленість науковців була зосереджена на вдосконаленні управлінської діяльності, управлінських уміннях, управлінської кваліфікації, проблемах формування професійної, інформаційної, комунікативної, іншомовної та інших компетентностей.

Проте формування управлінської компетентності у майбутніх фахівців соціальної сфери у закладах вищої освіти як педагогічна проблема комплексно і детально не досліджувалась. Аналіз сучасного стану професійної підготовки майбутніх фахівців соціальної сфери у системі закладів вищої освіти дозволили констатувати готовність майбутніх фахівців до сприйняття у XXI столітті нових форм професійної поведінки, зокрема і менеджерської.

Метою статті є дослідити цілеспрямованість формування управлінської компетентності у майбутніх фахівців соціальної сфери для забезпечення навчально-методичного процесу в закладах вищої освіти.

Методи дослідження - загальногалузеві, дослідницькі, інформаційні, діагностичні, предметно методичні.

\section{2. Теоретичні аспекти поняття «професійної підготовки» щодо формування управлінської компетентності}

Підготовка майбутніх фахівців соціальної сфери з метою формування управлінської компетентності, опановуючи в процесі навчання відповідні знання, які необхідні для набуття управлінських вмінь та навичок.

Оскільки об'єктом нашого дослідження визначено професійну підготовку студентів соціальної сфери вищих навчальних закладів ми вважали за необхідне з'ясувати ії особливості у вищих закладах освіти України. Для цього насамперед було досліджено семантику поняття: «професійна підготовка».

За результатами аналізу словникової та довідкової літератури з'ясовано, що цей феномен тлумачиться як формування і збагачення настанов, знань та умінь особистості з метою прискореного набуття навичок, які необхідні майбутньому спеціалісту для адекватного виконання специфічних завдань [9, с. 363]. Категорію «професійна підготовка» 
розглядають також у значенні сукупності вже здобутих спеціальних знань, навичок, умінь, якостей, досвіду праці та норм поведінки, що забезпечують можливість успішної роботи з певної професії [13, с. 390].

С. Гончаренко зазначає, що професійна підготовка - це сукупність знань, навичок і вмінь, оволодіння якими дає змогу людині працювати спеціалістом вищої, середньої кваліфікації або кваліфікованим робітником [2, с. 275], тобто процес підготовки зумовлює певний рівень кваліфікації спеціаліста.

У працях А. Грекова та С. Бондаревської професійна підготовка в себе включає суспільно-політичну, загальнофахову, психологічну та спеціальну підготовку, а також підготовку до керівництва і пошуку найбільш ефективних засобів навчання та виховання на основі запровадження педагогічної науки [3, с. 84].

В. Семиченко розуміє під сутністю поняття «професійна підготовка», що це одночасне забезпечення і виконання певного державного замовлення на спеціалістів. Науковець зазначає, що провідною цінністю професійної підготовки є діяльність, яка засвоюється [12, с. 179-184].

У Законі України «Про вищу освіту», професійна підготовка тлумачиться як «здобуття кваліфікації за відповідним напрямом підготовки або спеціальністю» [4, с. 1$]$.

Враховуючи сучасні вимоги до фахівців соціальної сфери вважаємо, що результатом процесу професійної підготовки спеціальності «Соціальна робота» слід розглядати набуту ними в процесі навчання систему компетентностей, що включає в себе і управлінську складову для здійснення професійної діяльності, професійних завдань соціального і управлінського характеру та здатність до їх постійного вдосконалення.

Оскільки підготовка фахівців соціальної сфери передбачає врахування фундаментальних знань і з інших галузей, предметом дослідження багатьох науковців була інтеграція знань 3 різних навчальних дисциплін $з$ метою покращення професійної підготовки майбутніх спеціалістів шляхом підвищення якісного рівня взаємозв'язків між елементами спеціальних і базових знань.

3 наукової точки зору важливим $є$ дослідження вітчизняної вченої Л. Сергієвої з формування управлінських навичок в учнівської молоді невиробничої сфери та отримані нею результати. Вона доводить, що «... 
лише теоретичне ознайомлення з навчальними курсами економічних дисциплін, основ підприємницької та управлінської діяльності не забезпечують цілеспрямованого формування в учнів управлінських навичок» [14].

На сучасному етапі у закладах вищої освіти запроваджуються заходи, які спрямовані на прискорення та поглиблення реформ національної системи освіти.

Проблема підготовки кадрів вищої кваліфікації в Україні не нова, зокрема в Національній стратегії розвитку освіти на 2012-2025 рр. вказано потреби ринку праці та сучасні виклики вищої освіти.

Успішне професійне становлення молодих фахівців та їх особистісного розвитку впродовж всього життя набули актуальності у сьогоднішній час. Проблема підготовки фахівців, яка сьогодні вирішується різними шляхами, в тому числі й через інтеграцію різних спеціальностей та реалізацію компетентнісного підходу.

Соціальна освіта - це необхідна та важлива умова поліпшення соціального становища країни і підвищення рівня професійної діяльності.

Прийнята Концепція неперервної освіти в Україні, яка грунтується на необхідності існування в суспільстві певного рівня загальної соціальної освіти, що зумовлено: необхідністю переходу до нових засад формування та розвитку соціальних знань; формуванням сучасних поглядів у майбутніх фахівців соціальної сфери 3 метою сприяння розвитку соціалізації суспільних процесів, підвищення рівня життя i добробуту; інтеграцію процесів навчання та виховання як складових системи освіти для формування світогляду сучасного фахівця.

У нашому дослідженні висвітлено терміни «управлінська діяльність» та менеджерська діяльність», які рівнозначні за смисловим значенням.

Аналіз теоретичних висновків науковців і практиків щодо професійної підготовки фахівців соціальної сфери до управлінської діяльності $є$ переконливим аргументом на користь необхідності уточнення суті поняття «професійна підготовка фахівців соціальної сфери», під яким ми розуміємо процес, результатом якого є формування комплексу компетентностей, в тому числі управлінської, необхідних майбутньому фахівцю для адекватного виконання професійних завдань, а також сукупність певних особистісних якостей, досвіду праці та норм поведінки, що забезпечують можливість успішної роботи з обраної професії і подальшого професійного й особистісного розвитку. 
Приєднання України до Болонського процесу підвищує вимоги до результату вищої професійної освіти, який сформовано в категоріях «компетенція» і «компетентність», що мають свою історію розвитку.

Поняття «компетентність» відображає інтегральну характеристику особистості. Водночас - це «не застигла сума характеристик» і «нестатична сутність». Оскільки людина - це «рухливий процес», «річка змін, а не шматок твердого матеріалу; це суцвіття можливостей», які мають властивість постійно змінюватися, то очевидним мотиваційним чинником $€$ те, що «кожний індивід має тенденцію стати самостійною, відмінною від інших, унікальною людиною» [13].

В процесі становлення компететнісного підходу до професійної підготовки фахівців І. Зимня виділяє три основних етапи:

- перший (1960-1970рр.) характеризується введенням до наукового апарату поняття «компетенція» та спроби роз'яснити відмінності між поняттями «компетенція» і «компетентність», які відносяться до самої людини, як суб'єкта діяльності (здоровий спосіб життя, ціннісно-змістовна, інтеграція знань, самоосвіта, саморозвиток);

- другий (1970-1990рр.) характеризується використанням понять «компетенція/компетентність» при оцінці професіоналізму в управлінні, менеджменті і відносяться до соціальної взаємодії людини і соціальної сфери;

- третій (90-ті рр. ХХ ст.) характеризується дослідженням компетентності як наукової категорії в системі освіти, яка відноситься до діяльності людини (вирішення пізнавальних завдань, предметнодіяльнісна, інформаційно-технологічна) [6].

У педагогічній енциклопедії наведено два значення компетентності:

1 - міра відповідності знань, умінь і досвіду осіб певного соціально-професійного статусу реальному рівню складності завдань, які він виконує, і проблем, які розв'язує;

2 - область повноважень керівного органу, посадової особи; коло питань, з яких вони мають право приймати рішення.

Дане джерело дає також порівняльну характеристику двох понять «компетентність» і «кваліфікація» і підкреслює, що компетентність на відміну від кваліфікації містить крім суто професійних знань і умінь, такі якості як: ініціатива, співпраця, спроможність працювати в групі, 
комунікативні здібності, вміння вчитися, оцінювати, логічно мислити, відбирати і використовувати інформацію [10, с. 237].

Потреба цивілізованого інтегрування незалежної України в світове співтовариство вимагає орієнтування майбутніх спеціалістів на передові методи господарювання, притаманні соціальним знанням та інформаційному суспільстві, оснащення їх сучасними знаннями і технологіями. Тому підготовка фахівців соціальної сфери до діяльності в сучасних умовах вимагає суттєвих змін. Процес розбудови української державності та життєздатність України у майбутньому значною мірою залежатимуть від того, чи зможе система освіти виховати нову генерацію ділових людей - управлінців, політиків тощо.

Передусім, притаманні глобальний стиль мислення, здатність діяти цілеспрямовано у складних нестабільних умовах та брати на себе есоціальну, кономічну, юридичну й моральну відповідальність за свої дії. Формування цих рис характеру в сучасної молоді за умов традиційної школи, що дісталась нам у спадок, є неможливим, оскільки освіта так і залишилася зорієнтованою на виховання «виконавців», нехай навіть і з високим рівнем знань. Тому у нашому дослідженні ми вважаємо правомірним проаналізувати зміст їхньої професійної підготовки, який складається з наукових знань і пов'язаних 3 ними уміннями та навичками.

Відомо, що існуюча організація, зміст і методика вищої професійної школи значно відстають від вимог життя, потреб і здібностей покоління, діючого в умовах швидких соціально-економічних змін. 3ВО країни не забезпечують належним чином готовності молоді до реалізації себе у галузі соціальної сфери, особливо за умов тенденції до нестабільності. Це призводить до гальмування адаптаційних процесів у молодих фахівців на виробництві, у сфері надання соціальних послуг. Оскільки випускник закладу вищої освіти може працювати на підприємстві, займаючи посаду відповідно до свого фаху, і може в майбутньому стати керівником, він повинен знати, як впливати на підлеглих, які методи використовувати, для досягнення максимально високих результатів, як сформувати свій колектив тощо. Тому цілком правомірним і доцільним є включення складової володіння методами управління та організації роботи колективу до змісту професійної підготовки фахівця соціальної сфери. 
Таким чином, ключовими словами при визначенні поняття «компетентність» $є$ знання, базові уміння, кваліфікація, інформованість, соціальна поведінка, прагнення до успіху в професійній діяльності тощо.

Професійна підготовка компетентного фахівця соціальної сфери, який готовий до роботи, є головною метою на зростаючій конкуренції на ринку праці.

\section{3. Формування управлінської компетентності у майбутніх соціальних працівників}

Оскільки предметом нашого дослідження визначено формування управлінської компетентності у майбутніх фахівців соціальної сфери, постає необхідність з'ясувати сутність та зміст.

В. Топоровський розглядає управлінську компетентність 3 позицій сучасного наукового бачення як філософсько-світоглядний, психолого-педагогічний та організаційно-технологічний потенціал професійних здібностей керівника школи, який визначається «спрямованістю діяльності на об'єкт управління з урахуванням його специфіки і характеру розвитку в соціально-освітньому середовищі» [16]. Науковець обгрунтовує двокомпонентну структуру управлінської компетентності, яка складається з базової складової професійної діяльності керівника та інноваційної складової як основи управління процесами розвитку педагогічного колективу й організації інноваційної роботи.

Філософський погляд на підготовку майбутніх менеджерів у вищих навчальних закладах як імператив Болонського процесу Т. Бірюкова зазначає, що сутність управлінської компетентності складають знання форм та методів управління. Нею розроблена і презентована структура управлінської компетентності менеджера, яка має три складові:

- стратегічна компетентність, що передбачає вміння аналізувати розвиток ситуації на тривалу перспективу з урахуванням усіх діючих факторів;

- функціональна компетентність орієнтує керівника на виконання управлінських функцій, тобто приймати рішення; організовувати, стимулювати, аналізувати результативність діяльності організації;

- соціальна компетентність «орієнтована на оптимізацію людського ресурсу в організації» і передбачає діяльність менеджера із забезпечення організації кваліфікованими кадрами; із надання повноважень, установлення системи мотивації і мінімально необхідного контролю 
їхньої діяльності, формування команди та створення умов для розвитку членів колективу [1].

Значний внесок у розроблення цього феномену зробила Г. Сльнікова. Нею виокремлено групу знань і умінь, які необхідні керівникові загальноосвітнього навчального закладу (знання: законодавчо-нормативні, методологічні, загальнотеоретичні, організаційно-технологічні; уміння: діагностично-прогностичні, організаційно-регулятивні, контрольно-корегуючі), та входять до складу цього концепту [7, с. 74-75].

Прослідковується тенденція вивчення питання управлінської компетентності менеджера соціальної сфери в тісному взаємозв'язку із соціальними, економічними процесами: управлінська компетентність $\epsilon$ складовою професійної компетентності фахівця; управлінська компетентність висвітлена як результат професійної підготовки фахівця соціальної сфери та оцінка його професійної діяльності в сфері менеджменту; сутність управлінської компетентності з точки зору фундаторів філософії розкриває спрямованість професійної діяльності керівника на об'єкт управління, враховуючи соціально-освітній простір, знання та уміння; фундатори педагогіки відображають управлінську компетентність як готовність та здатність ефективно здійснювати управлінську діяльність, застосовуючи знання, вміння та навички на підгрунті мотиваційно-особистісних якостей; управлінська компетентність - це об' ємна група знань, які грунтуються на законодавчо-нормативних, методологічних, загальнотеоретичних, організаційних та умінь діагностичних, організаційних, контрольних, які необхідні керівнику; здатність до діалогу в освітньому процесі.

\section{4. Міждисциплінарні зв'язки в процесі формування управлінської компетентності}

Принципи навчання в професійній освіті є основним орієнтиром у викладацькій діяльності. Їх порівнюють з мостом, який поєднує «теоретичні знання і уявлення» 3 педагогічною практикою. Вони завжди відображають залежність між об'єктивними закономірностями i цілями навчання. Інакше, це - методичне вираження пізнаних законів i закономірностей, знання про цілі, сутність, зміст, структуру навчання, виражене у формі, що дозволяє використовувати їх як регулятивні норми педагогічної практики. 
До тепер вважалось, що проблема реалізації міжпредметних зв'язків у педагогічній практиці вищої школи достатньо досліджена. Їй присвячені наукові праці відомих вітчизняних і зарубіжних учених-педагогів. Однак останні публікації в педагогічній і методичній літературі свідчать про пожвавлення інтересу науковців до означеної проблеми.

С. Гончаренко тлумачить принцип як «основні вихідні положення теорії навчання [3, с. 270]. У підручниках з педагогіки вищої школи наводиться визначення поняття «принципи» як загальний орієнтир для визначення змісту, засобів, форм, методів організації навчання [7, с. 221], основні положення, що визначають зміст, організаційні форми і методи навчальної роботи [7, с. 88]. Виявлені нами в попередньому розділі дисертації теоретичні основи формування у бакалаврів спеціальностей соціальної сфери свідчить про те, що у відповідь на нові виклики, що постають перед вітчизняними вищими навчальними закладами, розвиток сучасної вищої освіти потребує постійної реорганізації знань.

Таким чином, академічний світ має адаптуватися до міждисциплінарного характеру вирішення більшості суспільних проблем. Нові очікування на підготовку кадрів соціальної сфери із сформованою управлінською компетентністю слід розглядати у світлі цього імперативу. Сучасна вища професійна школа накопичила великий досвід підготовки всебічно розвинутих фахівців соціальної сфери на основі інтеграції знань. Традиційно в системі професійної підготовки кадрів у закладах вищої освіти широко використовуються міжпредметні зв'язки як актуальний засіб комплексного підходу до навчання і виховання особистості, що дозволяє розкрити в змісті навчання сучасні тенденції розвитку науки, які виникають під впливом процесів інтеграції: соціалізації, гуманізації, теоретизації, математизації, формалізації тощо.

Однак інтернаціоналізація ринку праці вимагає від фахівців соціальної сфери знань в галузі суміжних з його спеціальністю знань, вмінь комплексно використовувати їх для розв'язання наукових, виробничих і господарських завдань. У зв'язку з цим зросла потреба у фахівцях широкого профілю з такими якостями як освіченість, мобільність, конструктивність, практичність, здатність до співпраці та міжкультурної взаємодії, діяльності в нових умовах, що зумовило актуальність дослі- 
джень 3 проблеми подальшого розвитку і трансформації міжпредметних зв'язків в організації навчально-виховного процесу в ЗВО.

До тепер вважалось, що проблема реалізації міжпредметних зв'язків у педагогічній практиці вищої школи достатньо досліджена. Їй присвячені наукові праці відомих вітчизняних і зарубіжних учених педагогів. Однак останні публікації в педагогічній і методичній літературі свідчать про пожвавлення інтересу науковців до означеної проблеми. На сторінках наукових видань поновилась наукова полеміка 3 проблем міжпредметної інтеграції в навчанні студентів, міжпредметного підходу як загальнонавчального уміння, міжпредметних зв'язків як основи структури освітнього процесу, міжпредметної координації як педагогічної умови формування фахівців і розвитку в них мотивації до вивчення [6].

В процесі професійної підготовки фахівців соціальної сфери в 3ВО так чи інакше реалізує інтегральну функцію. При цьому виникає необхідність у подоланні суперечності між інтеграцією і диференціацією. Ця суперечність проявляється в необхідності одночасно вирішувати такі завдання як предметна побудова навчального плану і орієнтація процесу навчання на кінцевий результат, багатофункціональність у діяльності фахівців і вузька спрямованість навчання на розв'язання конкретних завдань. Ї̈̈ розв'язання потребує міжпредметного узгодження навчального матеріалу з різних дисциплін з метою запобігання дублювання, яке сьогодні є досить поширеним явищем у педагогічній практиці вищої школи, що гальмує досягнення бажаного результату в підготовці фахівців, оскільки утруднює усвідомлення специфіки вживання понять у різних предмета.

Значущість реалізації принципу міжпредметних зв'язків зростає у зв'язку з впровадженням компетентнісного підходу до підготовки фахівців у системі вищої професійної освіти. Розвиваючи ідею еволюції принципу міжпредметних зв'язків до міжпредметної координації як основи оптимізації змісту навчання, Т. Колеснікова наголошує, що випускник сучасного університету повинен мати сформовані уміння «затребувати і використати апарат кожної навчальної дисципіни в інтегративному зв'язку з іншими як засіб розв'язання завдань у пізнавальній і професійній діяльності. Аналіз психолого-педагогічної і методичної літератури дозволив нам з'ясувати види міжпредметних 
зв'язків. Це: фактичні зв'язки - зв'язки між навчальними предметами на рівні фактів; понятійні зв'язки - спрямовані на формування понять, загальних для споріднених предметів; теоретичні зв'язки - системи наукових знань у певній предметній області; філософські зв'язки відображають категорії матеріалістичної діалектики (загальне і особливе, причина і наслідок, необхідність і випадковість, можливість і дійсність, зміст і форма, сутність і явище).

За результатами вивчення ролі міжпредметних зв'язків в ракурсі компетентнісного підходу в підготовці майбутніх вчителів інформатики П. Нікітін дійшов висновку, що цей принцип відповідає знаннєвій парадигмі навчання, однак не в повній мірі відповідає вимогам компетентнісного підходу. Резюмуючи він зазначає, що принцип міжпредметних зв'язків «передбачає вже сформовані до певної міри статичні зв'язки між дисциплінами, оскільки визначає їх виключно через спільність теорій, законів, понять і методів», «не виокремлює компетентнісну сутність міждисциплінарних зв'язків, яка полягає в міждисциплінарному використанні знань і вмінь, а також цей принцип не визначає характер опанування ними в процесі навчання» [8, с. 318]. У зв'язку з цим виникла необхідність у розширенні принципу міжпредметних зв'язків. Автор доповнює його положенням про цілеспрямоване посилення зв'язків конкретної дисципліни з іншими, в тому числі «віддаленими» від неї, і про встановлення нових зв' язків. Йдеться про цілеспрямоване використання міжпредметних навчально-пізнавальних або компетентнісно-орієнтованих завдань як особливого виду міжпредметних зв'язків - міжпредметної координації. Такий підхід дозволяє створити освітній простір, своєрідну віртуальну навчальну міждисциплінарну лабораторію, в якій студент отримує можливість багаторазово використовувати знання 3 кожної дисципліни в нових умовах, за межами самої дисципліни, розвиває вміння використовувати знання і в професійній діяльності.

Узагальнюючи вищезазначене, можна зробити висновок, що принцип міжпредметних зв'язків у наукових працях вітчизняних і зарубіжних дослідників отримує подальшого розвитку - трансформується в принцип міжпредметної координації, який в нашому дослідженні ми визначаємо як основу формування управлінської компетеності у майбутніх фахівців соціальної сфери. Оскільки він забезпечує комплек- 
сність професійної підготовки студентів органічним поєднанням його фахової спрямованості та формуванням управлінської компетеності у процесі вивчення як професійно значущих дисциплін, так і предметів загальнонаукового циклу, до яких належить низка навчальних дисциплін які містять менеджерську складову.

Таким чином, реалізується міжпредметна координація в вивченні менеджменту та фаховою підготовкою студента. Враховуючи ці результати досліджень, вважаємо за необхідне виокремити і узагальнити вимоги до міжпредметної координації щодо узгодження роботи на рівні відповідних кафедр і окремих викладачів при формуванні управлінської компетентності. На нашу думку до таких вимог слід віднести:

- виокремлення дисциплін, зміст яких може бути використаний для формування управлінської компететності фахівців соціальної сфери;

- виділення менеджерських (управлінських) аспектів фахової дисципліни;

- усвідомлення викладачами менеджменту та фахових дисциплін комплексу цілей, які можна досягти при реалізації міжпредметної координації;

- надати студентам поняття про управлінську компетентність та iiі значення у майбутній професійній діяльності фахівця соціальної сфери;

- реалізація міжпредметних зв'язків у процесі проведення групових форм навчання, виконанні індивідуальних завдань та при організації систематичної самостійної роботи студентів;

- проведення занять 3 менеджменту 3 використанням методів навчальної діяльності, що актуалізують міжпредметні зв'язки (моделювання ситуацій, круглі столи за матеріалами індивідуальної роботи, майстер-класи, дискусії тощо).

Підготовка майбутніх фахівців соціальної сфери до діяльності в сучасних умовах вимагає суттєвих змін. Процес розбудови української державності та життєздатність України у майбутньому значною мірою залежатимуть від того, чи зможе система освіти виховати нову генерацію ділових людей. Практика економічно розвинутих країн свідчить, що цим професіоналам, передусім, притаманні глобальний стиль мислення, здатність діяти цілеспрямовано у складних нестабільних умовах та брати на себе соціальну, економічну, юридичну й моральну 
відповідальність за свої дії. Формування цих рис характеру в сучасної молоді за умов традиційної школи, що дісталась нам у спадок, $\epsilon$ неможливим, оскільки освіта так і залишилася зорієнтованою на виховання «виконавців», нехай навіть і з високим рівнем знань.

Тому цілком правомірним і доцільним є включення складової володіння методами управління та організації роботи колективу до змісту професійної підготовки майбутнього фахівця соціальної сфери. Отже, 3 метою реагування на виклики сучасного інформаційного суспільства і підготовки нового покоління фахівців для соціальної системи, заснованої на знаннях та інформації, науково-педагогічні закладів вищої освіти мають можливість постійно оновлювати зміст підготовки, відбирати і структурувати його згідно із загальнодидактичними і методичними принципами.

\section{5. Висновки}

Грунтуючись на аналізі педагогічних, методичних, філософських досліджень сутності, змісту та структури управлінської компетентності у фахівців соціальної сфери, фундаторами розкрито як складову професійної компетентності фахівця соціальної сфери, динамічним інтегрованим системним утворенням, який має прояв в управлінській діяльності. Управлінська діяльність в свою чергу є результатом управлінської підготовки фахівця соціальної сфери для оцінювання його професійної діяльності.

Отже, з метою реагування на виклики сучасного інформаційного суспільства і підготовки нового покоління фахівців для соціальної системи, заснованої на знаннях та інформації, науково-педагогічні колективи вищих навчальних закладів мають можливість постійно оновлювати зміст підготовки, відбирати і структурувати його згідно із загальнодидактичними і методичними принципами.

Професійна підготовка майбутніх фахівців соціальної сфери до управлінської діяльності є необхідною складовою, що потребує уточнення поняття «професійна підготовка фахівців соціальної сфери» 3 метою формування управлінської компетентності для ефективного виконання професійних обов'язків та можливості успішної роботи 3 обраної професії. 


\section{Список літератури:}

1. Бірюкова Т. Ф. Болонський імператив підготовки майбутніх менеджерів: автореф. дис. ... канд. філософ. наук: спец. 09.00.10 / Т. Ф. Бірюкова. К., 2006. - 18 c.

2. Гончаренко С. У. Український педагогічний словник / Семен Устимович Гончаренко. - К.: Либідь, 1997. - 376 с.

3. Гринчук О. І. Психологічні засади комунікативної підготовки майбутніх менеджерів: дис. канд. психол. наук: 19.00.07 / Гринчук Олександра Іванівна. - Івано-Франковськ, 2004. - 189 с.

4. Закон України “Про вищу освіту” // “Урядовий кур'єр”. - 15 травня 2002. - № 86. - C. 1-15.

5. Зеліковська О. О. Формування міжкультурної компетенції студентів вищих економічних навчальних закладів: автореф. дис. ... канд. пед. наук: спец. 13.00.04 «Теорія і методика професійної освіти» / О. О. Зеліковська. Чернігів, 2010. - 20 с.

6. Зимняя И. А. Ключевие компетенции - новая парадигма результата образования / Ирина Алексеевна Зимняя // Высш. образование сегодня. 2003. - № 5. - 2003. - С. 34-42.

7. Сльникова Г. Управлінська компетентність / Галина Єльнікова. К.: Ред. загальнопед. газ., 2005. - 128 с.

8. Педагогика : большая современная энциклопедия / сост. Е. С. Рапацевич. - Мн.: Современное слово, 2005. - 720 с.

9. Національна стратегія розвитку освіти в Україні на 2012-2021 pp. [Електронний ресурс]. - Режим доступу: http://www.mon.gov.ua/index.php/ua/ Назва $з$ екрана.

10. Педагогика: большая современная энциклопедия / сост. Е. С. Рапацевич. - Мн.: Современное слово, 2005. - 720 с.

11. Психолого-педагогический словарь для учителей и руководителей общеобразовательных учреждений / под ред. В. А. Мижерикова. - Ростовн/Д.: Феникс, 1998. - 544 с.

12. Роджерс К. Взгляд на психотерапию. Становление человека / Карл Роджерс. - М.: Прогресс, 1994. - 479 с.

13. Семиченко В. А. Пріоритети професійної підготовки: діяльнісний чи особистісний підхід? / В. А. Семиченко // Неперервна професійна освіта: проблеми, пошуки, перспективи: монографія / за ред. І. А. Зязюна. - К., 2000. C. 176-203.

14. Сергеєва Л. М. Формування управлінських навичок в учнів вищих професійних училищ невиробничої сфери: автореф. дис. ... канд. пед. наук: 13.00.04 / Л. М. Сергеєва. - К., 2000. - 21 с.

15. Топоровский В. П. Интегративный поход к формированию управленческой компетентности компетентности директора развивающейся школы: дис. ... доктора пед. наук: 13.00.01 / Топоровский Виталий Петрович. СПб, 2002. - 331 с.

16. Фіцула М. М. Педагогіка вищої школи: навч. посіб. / М. М. Фіцула. К.: «Академвидав», 2006. - 352 с. (Альма-Матер). 


\section{References:}

1. Biryukova, T.F. Bologna imperative for the training of future managers: author dis. ... cand. philosopher. science: special. 09.00.10 / T.F. Biryukova, 2006, 18 p. (in Ukrainian)

2. Goncharenko, S.U. Ukrainian pedagogical dictionary / Semyon Ustimovich Goncharenko, 1997, 376 p. (in Ukrainian)

3. Grinchuk, O.I. Psychological principles of communicative training of future managers: dis. cand. psychol. science: 19.00.07 / Grinchuk Alexandra Ivanovna, 2004, 189 p. (in Ukrainian)

4. Law of Ukraine "On Higher Education" // "Government Courier". May 15, 2002, no. 86, 1-15. (in Ukrainian)

5. Zelikovska O.O. Formation of intercultural competence of students of higher economic educational institutions: author's ref. dis. ... cand. ped. science: special. 13.00.04 «Theory and methods of professional education» / O.O. Zelikovska. Chernihiv, 2010. $-20 \mathrm{p}$.

6. Zimnyaya, I.A. Key competencies - a new paradigm of educational outcomes / Irina Alekseevna Zimnyaya // Vysh. education today. - 2003. - No. 5. P. 34-42. (in Ukrainian)

7. Yelnikova G. Management competence / Galina Yelnikova, 2005. - 128 p. (in Ukrainian) $720 \mathrm{p}$.

8. Rapatsevich, E.S. Pedagogy: a large modern encyclopedia. - Mn., 2005. -

9. National strategy for the development of education in Ukraine for 2012-2021 [Electronic resource]. - Retrieved from: http://www.mon.gov.ua/index.php/ua/ Name from the screen. (in Ukrainian)

10. Mizherinkov, V.A. Psychological and pedagogical dictionary for teachers and managers of general education institutions. 1998, 544 p. (in Ukrainian)

11. Rogers, K. A (2004). Look at psychotherapy. Becoming human / Carl Rogers, 479 p.

12. Semichenko, V.A. Priorities of professional training: activity or personal approach? / V.A. Semichenko // Continuing professional education: problems, searches, prospects: monograph / ed. I. Zyazyun, 2000, 176-203. (in Ukrainian)

13. Sergeeva, LM. Formation of management skills in students of higher professional schools of non-productive sphere: author's ref. dis. ... cand. ped. sciences: 13.00.04 / L.M. Sergeeva, 2000, 21 p. (in Ukrainian)

14. Toporovsky, V.P. Integrative approach to the formation of managerial competence of the competence of the director of the developing school: dis. ... doctor of pedagogical sciences: 13.00.01 / Toporovsky Vitaly Petrovich, 2002, 331 p.

15. Fitsula, M.M. Pedagogy of higher school: Textbook. way / M.M. Fitsula. K.: «Akademvydav», 2006. - 352 p. (Alma Mater). 